Jurnal BASTRA (Bahasa dan Sastra) : http://ojs.uho.ac.id/index.php/BASTRA

\title{
FUNGSI DAN MAKNA MANTRA KADIU SAFARA DESA LABUNTI KABUPATEN MUNA
}

\section{OLEH}

\author{
Yatni Sukarni ${ }^{1}$, La Ode Syukur ${ }^{2}$, dan Yunus ${ }^{3}$ \\ ${ }^{1}$ Alumni Jurusan Pend. Bahasa dan Sastra Indonesia, ${ }^{2,3}$ Dosen Jurusan \\ Pendidikan Bahasa dan Sastra Indonesia, Fakultas Keguruan dan Ilmu \\ Pendidikan Universitas Halu Oleo
}

\begin{abstract}
ABSTRAK
Tujuan penelitian ini adalah untuk mendeskripsikan fungsi dan makna mantra Kadiu Safara di desa Labunti Kabupaten Muna.Penelitian ini menggunakan metode penelitian lapangan.Jenis penelitian yaitu penelitian deskriptif-kualitatif. Data dalam penelitian ini adalah data lisan. Sumber data dalam penelitian ini adalah informan yaitu Kamokulano Liwu. Teknik pengumpulan data dalam penelitian ini menggunakan teknik wawancara, rekam, dan catat. Teknik analisis data dalam penelitian ini yaitu pendekatan struktural. Sesuai dengan hasil penelitian ini, fungsi mantra Kadiu Safara yaitu: Fungsi meletakan bhoru ke permukaan adalah sebagai bentuk penolak bala. Proses ini dipecaya dapat menghilangkan hal-hal buruk yang ada dalam kampong. Fungsi menyiram air yang sudah dimantrai ke masyarakat adalah sebagai mandi pembersihan diri dari dosa-dosa yang telah diperbuat pada tahun sebelumnya. Ketupat dan telur yang dibuang di laut berfungsi sebagai Ghotino Embu atau pemberian makan kepada penguasa laut agar mereka selalu dilindungi ketika sedang melaut. Sedangkan makna yang terkandung dalam mantra Kadiu Safara terdiri atas tiga bagian (1) makna mantra Kaetampisiha Oe:Makna mantra ketika turun ke air adalah untuk permohonan izin kepada penguasa laut agar mereka diberi kelancaran dalam melakukan ritual tersebut. Kamokulano Liwu meminta kepada Embu agar diberikan perlindungan selama proses berjalannya ritual. (2) makna mantra Kadiu Toba: masyarakat turun ke laut untuk mandi bermakna sebagai pembersihan diri sekaligus penghilang penyakit yang ada pada tubuh masyarakat. Kadiu Toba dianggap juga sebagai mandi mensucikan diri melepas semua dosa. (3) makna mantra Dhoa Kasalamata: sebagai bentuk rasa syukur masyarakat kepada Allah Swt, karena telah diberikan kesehatan, umur panjang dan sebagai penolak bala.
\end{abstract}

Kata kunci: fungsi, makna, kadiu safara 


\section{PENDAHULUAN}

\subsection{Latar Belakang}

Indonesia merupakan negara kepulauan yang memiliki berbagai macam suku bangsa dan budaya yang berbeda satu sama lain. Keanekaragaman budaya yang terdapat di Indonesia merupakan suatu bukti bahwa Indonesia merupakan negara yang kaya akan budaya, salah satunya adalah suku Muna.

Kebudayaaan suku Muna merupakan suatu kekayaan yang sangat bernilai karena menjadi ciri khas dari suatu daerah dan lambang kepribadian dari suku Muna. Sastra lisan merupakan bagian kebudayaan yang mengandung nilai-nilai kehidupan pada amsyarakat tertentu, yang tumbuh dan berkembang seiring dengan perkembangan zaman. Disisi lain, sastra lisan juga dapat digunakan sebagai alat pengenal bagi identitas suatu bangsa. Perkembangan suatu bangsa tidak terlepas dari peran kebudayaan berupa sastra lisan yang memiliki keunikan tersendiri, tentunya akan memiliki daya tarik bagi pecinta budaya di nusantara meupun dunia.

Sebagai warisan budaya, sastra lisan mengandung berbagai informasi mengenai ide, gagasan, pandangan, dan nilai-nilai budaya yang ada atau pernah ada dalam masyarakat. Keberadaan sastra lisan dapat dimanfaatkan dalam hubungannya dengan usaha pembinaan dan penciptaan karya sastra. Melalui penggalian sastra daerah, masyarakat kita akan lebih mengenal nilai-nilai budaya yang terkandung dalam karya sastra daerah. Nilai-nilai itu sangat penting untuk diwariskan kepada generasi muda sebagai pegangan dalam menyongsong era globalisasi.

Suku Muna di Sulawesi Tenggara memiliki berbagai jenis sastra lisan seperti cerita-cerita rakyat, nyanyiannyanyian rakyat, ungkapan tradisional, dan sebagainya. Jenis-jenis sastra lisan tersebut sangat menarik dan masih membutuhkan perhatian untuk dilestarikan dan dikembangkan.

Penyebaran sastra lisan di tengahtengah masyarakat tidak dilakukan secara terbuka melainkan diwariskan secara turun temurun dari generasi ke generasi berikutnya yang dilakukan secara lisan pula. Kebiasaan seperti ini lazim disebut sebagai tradisi lisan. Sastra lisan yang dimiliki suku Muna disampaikan secara lisan dengan menggunakan bahasa Muna, seperti sastra lisan yang berupa mantra.

Mantra merupakan sesuatu yang lahir dari masyarakat sebagai perwujudan keyakinan atau kepercayaan seseorang terhadap sesuatu. Dalam masyarakat tradisional, mantra bersatu dan menyatu dalam kehidupan sehari-hari. Seorang pawang atau dukun yang ingin menghilangkan atau menyembuhkan penyakit misalnya, dilakukan dengan membacakan mantra. Berbagai kegiatan yang dilakukan terutama yang berhubungan dengan adat biasanya disertai dengan pembacaan mantra. Hal tersebut tidak mengherankan mengingat bahwa terdapat suatu kepercayaan tentang berkah yang dapat ditimbulkan dengan pembacaan suatu mantra tertentu.

Mantra mempunyai hubungan yang erat dengan masyarakat. Masyarakat sangat meyakini bahwa pembacaan mantra merupakan wujud dari sebuah usaha untuk mencapai keselamatan dan kesuksesan. Untuk itu, keberadaan mantra menjadi penting dan tidak dapat dipisahkan dari kehidupan masyarakat.

Mantra Kadiu Safara merupakan mantra yang diucapkan oleh 
Kamokulano Liwu dalam tradisi Kadiu Safara yang dipercaya dapat menyembuhkan penyakit yang ada dalam kampung dan masyarakat juga percaya bahwa mantra Kadiu Safara merupakan penolak bala.

Penulis melakukan penelitian sastra lisan yang berkembang di kalangan masyarakat yaitu "Fungsi dan Makna Mantra Kadiu Safara Desa Labunti Kabupaten Muna". Tradisi Kadiu Safara terancam punah, karena kurangnya minat masyarakat untuk mengikuti tradisi tersebut. Dengan demikian penulis terdorong untuk menganalisis dan mengkaji kembali agar tradisi Kadiu Safara tidak hilang terutama di desa Labunti Kabupaten Muna.

Kadiu Safara merupakan tradisi yang dilakukan di laut oleh kamokulano liwu. Kamokulano liwu akan memantrai air, lalu air tersebut diberikan kepada masyarakat. Setelah masyarakat mendapat air yang sudah diberi mantra mereka lalu turun ke laut untuk mandi yang di sebut sebagai Kadiu Safara. Tradisi ini dilaksanakan setiap tahun pada saat bulan Oktober atau November, tujuannya agar desa Labunti terhindar dari penyakit dan kampung tidak akan terserang penyakit apapun, tradisi ini dilakukan sabagai penolak bala.

Kebudayaan daerah merupakan salah satu unsur yang turut memberikan corak kehiudupan masyarakat. Ini berarti kebudayaan daerah memberikan ciri khas kehidupan masyarakat suatu bangsa. Melalui kebudayaan daerah dapat terungkap berbagai pengalaman hidup, sikap, dan pandangan masyarakat sebagai manifestasi dari apa yang dipikirkan dan dirasakan oleh warga masyarakat. Oleh karena itu, masalah kebudayaan perlu mendapat perhatian yang baik. Salah satu budaya daerah yang perlu diperhatikan adalah sastra daerah terutama sastra lisan.

\subsection{Rumusan Masalah}

Adapun rumusan masalah dalam penelitian ini adalah

1. Bagaimanakah fungsi mantra Kadiu Safara di Desa Labunti Kabupaten Muna?

2. Bagaimanakah makna mantra Kadiu Safara di Desa Labunti Kabupaten Muna?

\subsection{Tujuan Penelitian}

Adapun tujuan yang ingin dicapai dalam penelitian ini adalah

1. Mendeskripsikan fungsi mantra Kadiu Safara di Desa Labunti Kabupaten Muna.

2. Mendeskripsikan makna mantra Kadiu Safara di Desa Labunti Kabupaten Muna.

\subsection{Manfaat Penelitian}

Manfaat yang diharapkan setelah melakukan penelitian ini adalah sebagai berikut :

1. Sebagai salah satu upaya pelestarian pencegahan dari ancaman kepunahan sastra daerah lisan dalam rangka memperkaya kebudayaan nasional di tengahtengah perkembangan zaman.

2. Sebagai bahan informasi tentang sastra daerah Kadiu Safara yang ada di Desa Labunti.

3. Sebagai bahan acuan penelitian selanjutnya terutama menyangkut masalah sastra daerah Muna.

4. Sebagai bahan ajar bagi pembelajaran sastra lisan di sekolah-sekolah. 


\section{KAJIAN PUSTAKA}

\subsection{Konsep Sastra}

Menurut Adi (2011: 16) adapun fungsi bahasa hanya memberitahukan, 6melainkan juga memberikan gambaran sebagai ungkapan arti tentang apa yang dilihat dan dirasakannya. Sastrawan memberikan gambaran yang menyampaikan arti tertentu tentang apa yang dilihatnya tersebut lewat bahasanya. Selain itu sastra dihargai karena berguna bagi hidup manusia. Sastra mengungkapkan berbagai pengalaman manusia agar manusia lain dapat memperoleh pelajaran baik, agar manusia lebih mengerti kepada manusia lain, agar manusia menjadi lebih baik hidupnya.

Sangidu (dalam Wicaksono, 2014: 2) menyatakan bahwa sastra adalah bagian dari masyarakat, kenyataan yang demikian mengilhami para pengarang untuk melibatkan dirinya dalam tata kehidupan masyarakat tempat mereka berada dan mencoba memperjuangkan posisi struktur social dan permasalahan yang dihadapi masyarakat. Sumardjo dan Saini (1997: 1) mengemukakan bahwa sastra adalah karya dan kegiatan seni yang berhubungan dengan ekspresi dan penciptaan, sedang tugas membuat batasan adalah kegiatan keilmuan.

\subsection{Konsep Sastra Lisan}

Sastra lisan merupakan hasil budaya manusia Indonesia yang telah ada sejak berabad-abad yang lampau.Sejak dahulu, kecintaan terhadap sastra sudah ada dalam masyarakat.Masyarakat telah terbiasa berkembang dan berpantim yang selalu diterapkan ke dalam kehidupan seharihari.Bahkan dalam berpidato dan berceramah pun.

Dalam perkembangannya, sastra lisan sebagai cerita yang berdimensi mite atau legenda masih disampaikan secara lisan dari satu generasi ke generasi lain. Menurut Bowra (dalam Uniawati, 2006: 8):

" Mite merupakan satu cerita yang bertujuan bukan umtuk menghibur, melainkan imtuk mengurangi atau menghilangkan kebingungan manusia masa prailmu karena penalaran mereka masih belum mampu untuk memahami segala masalah.

Sastra lisan merupakan bagian dari suatu kebudayaan yang tumbuh dan berkembang di tengah-tengah masyarakat dan diwariskan secara turun-temurun secara lisan sebagai milik bersama. Menurut Rusyana dan Raksanegara (dalam Uniawati, 2012: 10), sastra lisan itu akan lebih mudah digali karena ada unsurnya yang mudah dikenal oleh masyarakat.

\subsubsection{Ciri-ciri Sastra Lisan}

Sastra lisan sebagai hasil kesusasteraan masyarakat yang telah hadir di tengah kehidupan masyarakat sejak zaman lampau mempunyai ciriciri sebagai berikut:

a. tersebar secara lisan (Gaffar dalam Uniawati, 2006: 9);

b. anonim, yaitu karya sastra itu tidak dapat ditentukan pengarangnya;

c. religiusitas, yaitu karya sastra itu pada umumnya mengandung nilai agama dan kepercayaan yang dianut;

d. statis, yaitu karya sastra itu sangat lamban perkembangannya baik dari segi isi maupun bentuknya;

e. klise imajinatif, yaitu karya sastra itu selalu meniru karya sebelumnya baik dari segi isi maupun bentuknya; dan

f. ceritanya didominasi oleh mite. 


\subsection{Fungsi Sastra Lisan}

Secara sistematis sastra lisan di tengah-tengah masyarakat berfungsi (1) sebagai sistem proyeksi, (2) untuk pengesahan kebudayaan, (3) sebagai alat pemaksa berlakunya norma-norma sosial dan sebagai alat pengendali sosial, (4) sebagai alat pengendali pendidikan, (5) untuk memberikan suatu jalan yang dibenarkan oleh masyarakat agar dia dapat lebih superior dari pada orang lain, (6) sebagai alat untuk memprotes ketidakadilan dalam masyarakat, (7) untuk melarikan diri dari himpitan hidup sehari-hari (Hutomo dalam Asri dkk, 2008: 166). Selanjutnya Atmazaki (dalam Asri dkk, 2008: 167) "Sastra lisan antara lain berfungsi sebagai alat untuk membantu masyarakat atau nenek moyang umat manusia mengekspresikan gejolak jiwanya dan renungan tentang kahidupan".

\subsection{Pengertian Puisi}

Menurut pengertian lama, puisi ialah karangan yang terikat oleh syarat-syarat tertentu seperti jumlah baris dalam tiap-tiap bait, jumlah suku kata dalam tiap baris, irama, sajak (Natia, 2008: 4). Puisi menurut zamannya dapat dibedakan atas: (a) puisi lama, (b) puisi baru, (c) puisi modern. Perbadaan utama ketiga puisi diatas itu terletak pada sifat keterikatan dan kebebasan dalam mencipta.

Puisi merupakan hasil karya seni penyair yang bernilai rasa tinggi serta dapat menggairahkan jiwa pembacanya.Puisi juga dapat dikatakan sebagai suatu hasil tulisan kreatif yang berbentuk sajak, yang mengungkapkan ekspresi perasaan yang mendalam baik itu perasaan sedih, gembira, atau sedang jatuh cinta. Dengan adanya landasan pengimgkapan yang tidak sama, isi puisi juga berbeda-beda. Pada umumnya isi dari sebuah puisi mengungkapkan tentang realita yang ada dan terjadi di tengah masyarakat.Oleh karena itu, puisi bertujuan untuk menyampaikan gagasan, pandangan, dan pengalaman (Uniawati, 2006: 10-11).

\subsubsection{Puisi Lama}

Puisi adalah bentuk karangan yang terikat oleh rima, ritma, ataupun jumlah baris serta ditandai oleh bahasa yang padat.menutut zamannya, puisi dibedakan atas puisi lama dan puisi baru.Puisi lama adalah puisi yang terikat oleh aturan-aturan. Aturanaturan itu antara lain:
○ Jumah kata dalam 1 baris.
- Jumlah baris dalam1 bait.
- Persajakan ( rima)
- Banyak suku kata tiap baris.
○ Irama, (Hamidin, 2006).

\subsubsection{Jenis-Jenis Puisi Lama}

a) Mantra

Mantra merupakan puisi tua, keberadaannya dalam masyarakat melayu pada mulanya bukan sebagai karya sastra,melainkan lebih banyakberkaitan dengan adat dan kepercayaan. Mantra adalah ucapanucapan yang dianggap memiliki kekuatan gaib.

b) Pantun

Pantun adalah puisi yang bercirikan bersajak a-b-a-b, tiap bait 4 baris, tiap bait 4 baris, tiap baris terdiri dari 8-12 suku kata, 2 baris awal sebagai sampiran, 2 baris berikutnya sebagai isi. Pembagian pantun menurut isiya terdiri dari pantun anak, mudamudi, agama/nasihat, teka-tekijenaka.

c) Karmina

Karmina adalah pantun kilat seperti pantun tetapi pendek. 
d) Seloka

Seloka adalah pantun berkait.

e) Gurindam

Gurindam adalah puisi yang

berdirikan tiap bait 2

baris,bersajak a-a-a-a, berisi nasihat.

f) Syair

Syair adalah puisi yang bersumber dari Arab dengan cirri tiapbait 4 baris, bersajak a-a-a-a, berisi nasihat atau cerita.

g) Talibun

Talibun adalah pantun genap yang tiap bait terdiri dari 6, 8, ataupun 10 baris. Peribahasa

Peribahasa adalah suatu kiasan bahasa yang berupa kalimat atau kelompok kata yang bersifat padat, ringkas, dan berisi tentang norma, nilai, nasihat, perbandingan, perumpamaan,prinsip dan aturan tingkah laku (Hamidin, 2016).

\subsection{Konsep Mantra}

Istilah mantra berasal dari bahasa Sansekerta yang berarti jampi, pesona, atau doa. Pengertiannya kemudian berkembang menjadi puisi lisan yang merupakan bagian dari sastra lisan, dan sastra lisan merupakan bagian dari sastra folklore. Mantra memiliki survival yang cukup tinggi, buktinya masih bertahan sampai masa kini,walaupun terdapat banyak perubahan tata nilai masyarakat,kemajuan ilmu, dan teknologi yang mengancam kepunahannya (Mastrawijaya dalam Hamidin, 2016).

Menurut Redaksi Pm (2012: 21), mengemukakan bahwa mantra merupakan puisi tua keberadaannya dalam masyarakat melayu pada mulanya bukan sebagai karya sastra, melainkan lebih banyak berkaitan dengan adat dan kepercayaan.
Selanjutnya Natia (2008: 10), mengemukakan bahwa mantra ialah kata-kata yang mengandung hikmat dan kekuatan gaib.

\subsubsection{Jenis-jenis Mantra}

Berdasarkan sifat dan akibatnya mantra terhadap kehidupan manusia, Sukatman (dalam Hamidin, 2006) menggolongkan mantra menjadi mantra kejahatan (mantra ilmu hitam) dan mantra kebaikan (ilmu putih). Selain berdasarkan sifat dan akibatnya, mantra pula dapat digolongkan berdasarkan kandungan magisnya yaitu mantra syirik (mantra yang penggunanya bersekutu dengan setan) dan mantra tauhid (mantra yang penggunaannya percaya dengan Tuhan).

\subsubsection{Fungsi Mantra}

\subsubsection{Fungsi Mantra bagi Dukun}

Adapun fungsi mantra bagi dukun yaitu sebagai berikut:

a. Sebagai media untuk menunjukkan kemampuan, selain menjalankan tugasnya sebagai fasilitator untuk bermantra, dukun atau pawang juga mempunyai peluang untuk mengaktualisasikan dirinya melalui mantra yang dibacakannya. Seorang dukun atau pawang berusaha untuk bermantra dengan sebaik-baiknya karena dalam prosesi pemantraan itu ada tugas yang diemban sekaligus, yakni menyampaikan maksud bermantra atau permohonan kepada Tuhan, dewa, dan kepuasan diri sang dukun jika tercapai maksud mantra tersebut.

b. Sebagai media untuk menyebarluaskan agam

c. Sebagai media untuk menyalurkan hobi 
d. Sebagai media untuk mencari nafkah.

\subsubsection{Fungsi Mantra bagi Masyarakat}

Selain berfungsi bagi dukun atau pawang, mantra berfungsi juga untuk masyarakat, yaitu sebagai berikut berikut:

a. Sebagai fungsi religi bagi sebagian masyarakat, pada umumnya mantra yang berupa permohonan kepada Tuhan merupakan fungsi religi yang utama,

b. Mantra sebagai fungsi pendidikan, misalnya mantra yang berisi permohonan kepada Tuhan dan mantra untuk tumbuh-tumbuhan. Mantra tersebut memberikan pendidikan kepada masyarakat bahwa manusia harus patuh, bersyukur, memohon kepada Tuhan Sang Pencipta, bersahabat, memelihara, mengatur alam termasuk hewan dan tumbuhtumbuhan yang menjadi sumber hidup (Hamidin, 2006).

\subsection{Konsep Makna}

Semantik yang semula berasal dari bahasa Yunani, mengandung makna to signify atau memaknai.Sebuah istilah teknis, semantik mengandung pengertian "studi tentang makna". Dengan anggapan bahwa makna menjadi bagian dari bahasa, maka semantik merupakan bagian dari linguistik (Aminuddin, 2011: 15).Semantic menelaah lambinglambang atau tanda-tanda yang menyatakan makna, hubungan makna yang satu dengan yang lain, dan pengaruhnya terhadap manusia dan masyarakat (Tarigan, 1985: 7).

Selanjutnya, Aminuddin (2011: 52) mengatakan bahwa makna yang bermula dari kata ternyata juga memiliki hubungan erat dengan (1) sistem sosial budaya maupun realitas luar yang diacu, (2) pemakai, maupun (3) konteks sosial-situasional dalam pemakaian. Grice \& Bolinger (dalam Aminuddin, 2011: 52-53) mengatakan bahwa makna ialah hubungan antara bahasa dengan dunia luar yang telah disepakati bersama oleh para pemakai bahasa sehingga dapat saling dimengerti.

\subsection{Konsep Kadiu Safara}

Kadiu Safara merupakan tradisi mandi di air laut yang telah diberi mantra.Mantra Kadiu Safara yaitu mantra yang diucapkan oleh kamokulano liwu dalam tradisi Kadiu Safara yang dipercaya dapat menyembuhkan penyakit yang ada dalam kampung dan masyarakat juga percaya bahwa Kadiu Safara merupakan penolak bala.Tradisi Kadiu Safara disebut juga sebagai mandi taubat atau mandi untuk mensucikan diri.

\subsection{Pendekatan Struktural}

Pendekatan struktural, sering juga dinamakan pendekatan objektif, pendekatan formal, atau pendekatan analitik, bertolak dari asumsi dasar bahwa karya sastra sebagai karya kreatif memiliki otomi penuh yang harus dilihat sebagai suatu sosok yang berdiri sendiri terlepas dari hal-hal lain yang berada di luar dirinya. MenurutRatna (2008: 73) menyatakan bahwa pendekatan objektif merupakan pendekatan yang terpenting sebab pendekatan apa pun yang dilakukan pada dasarnya bertumpu atas karya sastra itu sendiri.Bila hendak dikaji atau diteliti, maka yang harus dikaji dan diteliti adalah aspek yang membangun karya tersebut seperti tema, alur, latar, penokohan, gaya penulisan, gaya bahasa, serta 
hubungan harmonis antaraspek yang mampu membuatnya menjadi sebuah karya sastra (Semi, 1990: 67).

\section{METODE DAN TEKNIK PENELITIAN}

\subsection{Jenis Penelitian dan Metode Penelitian}

\subsubsection{Jenis Penelitian}

Jenis penelitian yang digunakan adalah jenis penelitian deskriptifkualitatif.Penggunaan jenis ini dimaksudkan untuk mendeskripsikan secara langsung fungsi dan makna mantra Kadiu Safara diDesa Labunti Kabupaten Muna.Di samping itu, karena yang menjadi sasaran dalam penelitian dideskripsikan tanpa disertai perhitungan statistik, maka dalam penelitian inipun menggunakan jenis kualitatif.Jenis kualitatif memberikan perhatian terhadap data alamiah, data dalam hubungannya dengan konteks keberadaannya.

\subsubsection{Metode Penelitian}

Metode penelitian adalah penelitian lapangan.Dikatakan demikian, karena untuk mendapatkan data mengenai ritual Kadiu Safara, peneliti secara langsung turun ke lapangan untuk mangamati dan mengmpulkan data.

\subsection{Data dan Sumber Data}

\subsubsection{Data}

Data yang digunakan dalam data lisan, data lisan yang dimaksud adalah data yang berasal dari tuturan lisan informan yang dipakai atau diungkapkan dalam Kadiu Safara di Desa Labunti Kabupaten Muna.

\subsubsection{Sumber data}

Sumber data dalam penelitian ini adalah informan. Informan tersebut ditulis secara langsung berdasarkan pengalaman atau pengetahuan informan tentang Kadiu safara. Informan yang dimaksud yaituseperti imam kampung dan orang tua kampung atau disebut Kamokulano Liwu.

\subsection{Teknik Pengumpulan Data}

Adapun data dalam penelitian ini merupakan data lapangan yang dikumpulkan dengan menggunakan teknik:

1. Teknik wawancara.

Teknik ini digunakan untuk berdialog langsung dengan La Ode Wahyu selaku Kamokulano Liwu dan menjadi informan untuk mendapatkan data mengenai mantra dalam Kadiu Safara.

2. Teknik rekam.

Teknik rekam ini digunakan karena terbatasnya kemampuan penulis untuk mengingat seluruh hasil wawancara dilapangan, maka penulis menggunakan teknik rekam setiap wawancara.Hal ini dilakukan karena peneliti guna memperoleh data yang lengkap dari segala bentuk aspek terpenting yang menjadi sasaran penelitian.Penulis merekam tuturan mantra Kadiu Safara dengan menggunakan handphone.

3. Teknik catat.

Teknik catat digunakan untuk mencatat data hasil wawancara yang dilakukan.Selain itu, teknik catat juga digunakan untuk mencatat hal-hal penting untuk mendapatkan informasi tambahan.

\subsection{Teknik Analisis Data}

Teknik analisis data dalam penelitian ini digunakan dengan menggunakan pendekatan struktural.Tujuannya adalah untuk mengidentifikasi fungsi dan makna tuturan mantra dalam tradisi Kadiu 
Safara di Desa Labunti Kabupaten Muna.

Adapun prosedur pengolahan data dilakukan dengan tahapan-tahapan sebagai berikut:

1. Transkripsi yaitu memindahkan data rekaman ke hasil lisan

2. Klasifikasi data, yaitu semua data yang dikumpulkan sesuai dengan karateristik data yang dibentuk

3. Penerjemahan data, yaitu tahap ini semua data yang telah dikelompokkan langsung diterjemahkan ke dalam bahasa indonesia.

4. Deskripsi hasil analisis data.

\section{HASIL DAN PEMBAHASAN}

\subsection{Gambaran Umum Kadiu Safara}

Kadiu Safara merupakan salah satu bentuk tradisi lisan yang dilakukan oleh masyarakat Muna secara turun-temurun, khususnya di Desa Labunti Kabupaten Muna.Kadiu Safara merupakan suatu kepercayaan masyarakat Muna khususnya di Desa Labunti yang diyakini dapat menghilangkan penyakit dalam kampung dan juga digunakan sebagai penolak bala. Kadiu Safara disebut juga sebagai mandi taubat atau mandi suci yaitu mandi membersihkan diri dari segala perbuatan yang telah dilakukan dalam satu tahun.

$$
\text { Mantra Kadiu Safara }
$$

sebelumnya menggunakan bahasa daerah Muna.Akan tetapi, setelah dipengaruhi kajian Islami mantra tersebut tidak sepenuhnya menggunakan bahasa Muna. Bahasa Muna yang digunakan dalam mantra tersebut hanya terdapat ketika akan turun ke laut dan pada saat membaca Dhoa Kasalamata saja.

\subsubsection{Langkah-langkah Prosesi} Kadiu Safara

1. Kaetampisiha Oe (Menimba air)

2. Kadiu Toba (Mandi Tobat)

3. Dhoa Kasalamata

(Doa

Keselamatan)

4.2 Data Mantra Kadiu Safara dan Terjemahannya

a. Mantra Kaetampisiha Oe ( mantra menimba air)

Mantra Dosampu Welo Oe (mantra turun ke air):

Netamu kawu aitu ompu kahalamani tipandehaono, pata tipandehaono taesalo ne Allah ta'ala.

(T.b) Ya Allah, kami memohon kepada Engkau ampuni kesalahan kami baik yang disengaja ataupun yang tidak disengaja.

Koetaeghawa karindi, koetaeghawa kapana segala bala damolapasiemu gholeitu

(T.b) Jangan berikan kami rasa sakit dan penderitaan, segala kesalahan kami bersihkan hari ini

Notulumigho tora Allah ta'ala nafosampugho kasalamati, kaghosa, radhaki, katangka sumada

(T.b) Berikanlah kami pertolongan Ya Allah, berikanlah kami keselamatan, kesehatan, rejeki, dan kekuatan yang sesungguhnya.

Da fotulumigho tora Allah ta'ala barakatino Nabi Muhammad.

(T.b) Ya Allah, berikan kami pertolongan dan berkahilah Nabi Muhammad.

Mantra Welo Oe (ketika dalam air): Allahumma sholi ala sayidina Muhammad (3x)

(T.b) Ya Allah, limpahkan rahmat kepada junjungan kami

Subhanallahi walhamdulillah walaillahailalla wallahuakbar (3x)

(T.b) Maha suci bagi Allah, segala puji bagi Allah, tidak ada satu Tuhan pun 
yang disembah kecuali Allah, dan Allah maha besar

Lailla hailla anta manfilkum Aalla

(T.b) Tidak ada yang berhak diibadahi dengan benar kecuali Allah.

\section{b. Mantra Kadiu Toba (mantra mandi Tobat)}

Astagfirullah hal adzim al ladzi laa ilaha illa huwal hayyul qayyum wa atubu ilaih

(T.b) Aku meminta ampun kepada Allah yang maha Agung dan aku bertaubat kepada-Mu

Allahumma anta robbi, laa ilaha illa anta, kholaqtani wa ana abduka, wa ana 'alaa' ahdika wa wa'dika mastahto'tu, audzubika, min syarri maa shona'tu, abu'u laka bi ni'matika' alaiyya wa yaghfiru dzunuuba illa anta (T.b) Ya Allah Engkau adalah Rabbku, tidak ada Rabb yang hendak disembah kecuali Engkau.Engkaulah yang menciptakanku.Aku berlindung kepada-Mu dari kejelekan yang kuperbuat.Aku mengakui nikmat-Mu kepadaku dan aku mengakui dosaku, oleh karena itu, ampunilah aku.Sesungguhnya tiada yang mengampuni dosa kecuali Engkau.

\section{c. Dhoa Kasalamata (doa keselamatan)}

Ompu Allah ta'ala taesalo kasalamati bhe kaghosa, tubari kasami ilmu metaano, owa kasami umuru mewanta, radhaki balano, ampuni kasami dhosa mani bhari-bharie, kahala mani neompu mani bhe kahala mani nemanusia. Ompuku Allah ta'ala fekakodoho kasami bala, fekamaho kasami rajaki.Mina beompu nesomba aтрати Allah ta'ala nesomba dakotukotughuhano, amapu Allah ta'ala fowaghono kaghosa bhe kasalamati.

(T.b) Ya Allah ya Tuhanku, kami meminta keselamatan dan kesehatan, berikan kami ilmu yang baik, berikan kami umur panjang, rejeki yang banyak, ampuni segala dosa-dosa kami, dosa kepada Engkau dan dosa kepada manusian.Ya Allah ya Tuhanku, jauhkan kami dari segala bahaya dan dekatkan kami dari rejekimu.Tidak ada Tuhan yang patut disemba hanya Allah Swt, yang memberi kesehatan dan keselamatan.

Allahumaftah lana abwabal khairi wa abwabal barakati wa abwabal ni'mati wa abwabal rizki wa abwabal kuwati wabwabash shihhati waabwabas salamati wa abwabal afiyati wa abwabal jannati.

(T.b) Ya Allah, bukakanlah bagi kami pintu kebaikan, pintu keberkahan, pintu nikmat, pintu rizki, pintu kekuatan, pintu kesehatan, pintu keselamatan, pintu kebugaran, pintu surga.

Allahumma inni as-alukal' afwa wal' afiyahtan fiddunya wal akhiroh

(T.b) Ya Allah aku memohon kepada$\mathrm{Mu}$ ampunan dan keselamatan di dunia dan akhirat.

Laa hawla wa laa quwwata illa billahil aliyil adzim salallahu ala sayidina muhammad wa ala alihi washabihi wasalam.

(T.b) Tidak ada kuasa bagi hamba untuk menolak kejelekan dan tidak ada kekuatan untuk meraih kebaikan selain dengan kuasa Allah, sholawat dan salam semoga tercurahkan kepada nabi Muhammad dan para sahabatnya.

Rabbana atinna fiddunya hasanataw wafil akhirati hasanataw waqina adzaabannar.

(T.b) Ya Allah, berilah kami kebajikan di dunia, kebajikan di akhirat, dan peliharalah kami dari adzab api neraka. 
4.3 Fungsi Mantra Kadiu Safara

4.3.1 Fungsi Mantra Kaetampisiha Oe (Menimba Air)

Adapun fungsi mantra Kaetampisiha Oe sebagai berikut:

a. Fungsi meletakan bhoru ke permukaan air sehingga dibawa oleh arus air menuju laut adalah sebagai bentuk penolak bala. Proses ini dipecaya dapat menghilangkan hal-hal buruk yang ada dalam kampung.

b. Timba terbuat dari tempurung kelapa berfungsi sebagai symbol keberuntungan karena zaman dulu masyarakat tidak memiliki tempat untuk menimba air sehingga mereka membuat timba dari tempurung kelapa.

c. Dilakukan di mata air yang berfungsi sebagai bentuk pembersihan diri karena mata air merupakan sumber air yang alami dan bersih.

d. Fungsi dari mantranya yaitu sebagai bentuk permohonan kepada Allah Swt, agar dapat menghilangkan penyakit yang ada pada diri masyarakat.

\subsubsection{Fungsi Kadiu Toba (Mandi Tobat)}

Adapun fungsi mantra Kadiu Toba (mandi tobat)adalah sebagai berikut:

a. Fungsi menyiram air yang sudah dimantrai ke masyarakat adalah sebagai mandi pembersihan diri dari dosa-dosa yang telah diperbuat pada tahun sebelumnya.

b. Mandi di laut berfungsi sebagai pembersihan diri dan dengan niatan agar semua penyakit dan semua bala yang ada menjadi hilang terbawa oleh arus laut.

c. Sebagai bentuk mandi mensucian kembali diri kita.

\subsubsection{Fungsi Dhoa Kasalamata (doa Keselamatan)}

Adapun fungsi mantra Dhoa Kasalamata (doa keselamatan) adalah sebagai berikut:

a. Ketupat dan telur yang dibuang di laut berfungsi sebagai Ghotino Embu atau pemberian makan kepada penguasa laut agar mereka selalu dilindungi ketika sedang melaut.

b. Sebagai permohonan kepada Allah Swt, agar selalu diberikan kesehatan dan umur panjang.

c. Sebagai permohonan kepada Allah Swt, agar diberikan keselamatan dan dijauhkan dari segala bahaya.

d. Sebagai permohonan kepada Allah Swt, agar diberikan rejeki yang bagus dan mendapat pekerjaan yang lancar.

e. Sebaagai permohonan kepada Allah swt, agar dijauhkan dari segala bahaya yang menimpa.

\subsection{Makna Mantra Kadiu Safara 4.4.1 Makna Mantra Kaetampisiha Oe}

Mantra Kaetampisiha Oe sebelum turun ke air laut bermakna sebagai permohonan izin KamokulanoLiwu kepada Allah Swt, agar diberikan kelancaran dan keberkahan dalam melakukan tradisi Kadiu Safara.Setelah berada di air laut Kamokulano Liwu memberi mantra selanjutnya yang bermakna sebagai bentuk permohonan Kamokulano Liwu kepada Allah Swt, agar masyarkat yang mengikuti tradisi ini diberikan keselamatan dan kesehatan.

\subsubsection{Makna Mantra Kadiu Toba (Mandi tobat)}

Ungkapan mantra Kadiu Toba bermakna sebagai pembersihan diri dari perbuatan buruk yang telah 
dilakukan di tahun sebelumnya baik yang disengaja ataupun tidak disengaja. Dalam Kadiu toba masyarakat akan disiram dengan air yang sudah dimantrai yang bermakna sebagai penghapus dosa atau pembersihan diri dari dosa-dosa yang telah dilakukan.

\subsubsection{Makna Mantra Dhoa Kasalamata (doa keselamatan)}

Makna ketupat dan telur adalah sebagai pelengkap sesajian yang ditujukan untuk penguasa laut agar masyarakat selalu diberikan perlindungan dan keselamatan ketika sedang melaut.ketupat dan telur dibuang ke laut oleh sebagian masyarakat yang mempercayai hal tersebut.

Di sisi lain, makna mantraDhoa Kasalamata adalah sebagai bentuk rasa syukur masyarakat kepada Allah Swt, karena telah diberikan kesehatan dan umur panjang. Sebagai bentuk pemohonan kepada Allah Swt, agar selalu didekatkan dari rejeki, diampuni dosa-dosanya, dijauhkan dari segala bahaya, dan meminta keselamatan dalam menjalani aktivitas.Dalam membaca dhoa kasalamata, masyarakat menyediakan ketupat dan telur sebagai pelengkap sesajian yang bermakna sebagai bekal untuk roh orang mati.Selain itu, pembacaan dhoa kasalamata juga bermakna sebagai penolak bala.

\section{PENUTUP}

\subsection{Kesimpulan}

Berdasarkan uraian dalam pembahasan hasil penelitian tentang Fungsi dan Makna Mantra Kadiu Safara Desa Labunti Kabupaten Muna, dapat disimpulkan sebagai berikut: a) Fungsi mantra Kadiu Safara yaitu: (1) Kaetampisiha Oe (Menimba Air):
Fungsi meletakan bhoru ke permukaan air sehingga dibawa oleh arus air menuju laut adalah sebagai bentuk penolak bala. (2) Mantra Kadiu Toba (mandi tobat): sebagai bentuk mandi mensucian kembali diri kita. (3) Mantra Kasalamata (keselamatan): sebagai permohonan kepada Allah Swt, agar diberikan keselamatan dan dijauhkan dari segala bahaya, sebagai permohonan kepada Allah Swt, agar selalu mendapat rejeki dan pekerjaan yang lancar, sebagai permohonan kepada Allah swt, agar dijauhkan dari segala bahaya yang menimpa. (b)Makna mantra Kadiu Safara terdiri dari tiga makna yaitu: (1) Makna Mantra Kaetampisiha Oe (menimba air): Ungkapan mantra ketika bhoru diletakan dipermukaan air bermakna sebagai pembawa semua hal-hal buruk yang ada dalam kampong.(2) Makna mantra Kadiu Toba: sebagai penghapus dosa atau pembersihan diri dari dosa-dosa yang telah dilakukan. (3) Makna mantra Dhoa Kasalamata:Sebagai bentuk pemohonan kepada Allah Swt, agar selalu diberikan umur panjang, didekatkan dari rejeki, diampuni dosadosanya, dijauhkan dari segala bahaya, dan meminta keselamatan dalam menjalani aktivitas.

\subsection{Saran}

Berdasarkan kesimpulan tersebut, penulis menyarankan beberapa hal sebagai berikut:

1. Penelitian ini belum bisa dikatakan lengkap dan sempurna dalam mengkaji sastra daerah masyarakat Muna. Masih banyak sastra daerah Muna yang perlu diteliti dan diselamatkan dari ancaman kepunahan. Oleh karena itu, perlu adanya penelitian selanjutnya untuk turut mengambil bagian 
dalam penyelamatan sastra daerah yang merupakan asset untuk memperkaya kebudayaan nasional.

2. Perlu penelitian lanjutan dan pengkajian yang lebih mendalam lagi mengenai mantra Kadiu Safara di Kabupaten Muna khususnya di Desa Labunti agar tidak hilang atau terancam punah serta masih ada dan hidup pada generasi berikutnya.

\section{DAFTAR PUSTAKA}

Adi, Ida Rochani. 2011. Fiksi Populer: Teori dan Metode Kajian. Yogyakarta: Pustaka Pelajar.

Ahimsa-Putra, Heddy Shri. 2009. Strukturalisme Levi-Strauss: Mitos dan Karya Sastra. Yogyakarta: Kepel Press.

Amir, Adriyetti.2013. Sastra Lisan Indonesia. Yogyakarta: Andi.

Aminuddin. 2011. Semantik: Pengantar Studi Tentang Makna. Bandung: Sinar Baru Algensindo.

Asri dkk. 2008. Bunga Rampai: Hasil Penelitian Kesastraan Tuturan Ritual pada Perkawinan Adat Suku Tolaki. Kendari: Kantor Bahasa Provinsi Sulawesi Tenggara.

Haruddin dkk. 2008. Bunga Rampai: Hasil Penelitian Kesastraan Mantra Petani Poleang. Kendari: Kantor Bahasa Provinsi Sulawesi Tenggara.

Jabrohim. 2014. Teori Penelitian Sastra. Yogyakarta: Pustaka Pelajar.

Kridalaksana, Harimurti. 2011. Kamus Linguistik Edisi Keempat.
Jakarta: PT Gramedia Pustaka Utama.

Natia, I.K. 2008.Apresiasi Sastra Indonesia. Surabaya: Bintang.

Nurgiyantoro, Burhan. 2010. Teori Pengkajian Fiksi. Yogyakarta: Gadjah Mada University Press

Piaget, Jean. 1995. Strukturalisme. Jakarta: Yayasan Obor Indonesia.

Rahmawati. 2014. Ungkapan Tradisional Muna. Kendari: Kantor Bahasa Provinsi Sulawesi Tenggara.

Ratna, Nyoman Kutha. 2008. Teori, Metode, dan Teknik Penelitian Sastra. Yogyakarta: Pustaka Pelajar.

Semi, Atar. 1990. Metode Penelitian Sastra. Bandung: Angkasa.

Sukada, Made. 1993. PembinaanKritik Sastra Indonesia.Bandung: Angkasa Bandung.

Sumardjo, Jakob dan Saini. 1997. Apresiasi Kesusastraan. Jakarta: PT Gramedia Pustaka Utama.

Tarigan, H.G. 1985. Menyimak Sebagai Suatu Keterampilan Berbahasa. Bandung: Angkasa.

Teeuw, A. 2015.Sastra dan Ilmu Sastra.Jakarta: Balai Pustaka.

Uniawati. 2006. Fungsi Mantra Melaut pada Masyarakat Suku Bajo di Sulawesi Tenggara. Kendari: Kantor Bahasa Provinsi Sulawesi Tenggara.

Uniawati. 2012. Mantra Melaut Suku Bajo (Interpretasi Semiotik Riffaterre). Kendari: Kantor Bahasa Provinsi Sulawesi Tenggara.

Wicaksono, Andi. 2014.Pengkajian Prosa Fiksi. Yogyakarta: Garudhawaca 